\title{
Weed's Vegetation Analysis of Centella (Centella asiatica L. Urban) Plantations
}

\author{
Dian Susanti*, Devi Safrina and Nur Rahmawati Wijaya \\ Medicinal Plant and Traditional Medicine Research and Development Center, National Institute \\ Health Research and Development, Ministry of Health, Karanganyar, Indonesia \\ ${ }^{*}$ Corresponding author: dian.ssanti@gmail.com
}

\begin{abstract}
Centella (Centella asiatica L. Urban) originally is a wild plant that is being cultivated to be medicinal and cosmetics raw material. The process of centella cultivation is relatively easy and can be grown in a variety of altitudes. One obstacle in centella cultivation is weed growth. The proper handling of weeds in centella plantation requires data on the weed types and characteristics. This research aimed to determine the weed types and the amount of weed found in centella cultivation. Sampling was carried out purposively based on the presence of weeds in the cultivation area. Weed inventory was carried out using linear vegetation methods in 12 plantation beds of centella, with a size of $6 \mathrm{~m}^{2} \times 2 \mathrm{~m}^{2}$ each. Observations were made during weeding on one cropping season. Weed inventory was carried out by recording the number of species and number of individual weed and taking documentation of weeds that were recorded for identification purposes. Research data were analyzed by using vegetation analysis. The weed vegetation analysis on centella plantations showed that there were 35 species of weeds identified from 20 plant families. Cyperus rotundus L. dominates the weed vegetation in centella plantations because of its high adaptability and its allelochemical exudates. To sustainably cultivate the centella, proper techniques of weed controls need to be applied by considering the nature of Cyperus rotundus $\mathrm{L}$.
\end{abstract}

Keywords: centella; vegetation analyze; weed community

Cite this as: Susanti, D., Safrina, D., \& Wijaya, N. R. (2021). Weed's Vegetation Analysis of Centella (Centella asiatica L. Urban) Plantations. Caraka Tani: Journal of Sustainable Agriculture, 36(1), 110-122. doi: http://dx.doi.org/10.20961/carakatani.v36i1.41269

\section{INTRODUCTION}

Centella (Centella asiatica L. Urban) is a perennial medicinal plant of the Apiaceae family. Centella grows creeping and it is a bit aromatic. The dispersion area of centella is quite extensive, including tropical and subtropical regions (Hashim, 2011; Jahan et al., 2012). Centella usage in food and drinks increased because of its antioxidant, antimicrobial, cytotoxic, neuro-protective and its other properties. There are studies related to the nature and action mechanism of the bioactive constituents of centella plants namely triterpenic acid (asiatic acid madekasat acid), triterpenic saponins (madecassoside and asiaticoside), flavanoids and other phenolic compounds (Januwati et al., 2002; Seevaratnam et al., 2012). Centella is also used in the drugs and cosmetics industry because of its variety of properties (Sari and Diana, 2017). The increasing demand of centella as an industrial raw material requires standardization in the medicinal plant cultivation system that meets the requirements of the Good Agriculture Practice (GAP) (Menkes RI, 2013).

In the cultivation of medicinal plants, external or environmental factors need to be considered

\footnotetext{
* Received for publication April 21, 2020

Accepted after corrections December 15, 2020
} 
to produce a product with the required quality and quantity (Susanti and Safrina, 2018). Obstacle of medicinal plants cultivation are weeds or plants that interfere with plant growth and development. Weed is a competitor for the main plants in utilizing nutrients, water, light and space. It reduces the efficiency of fertilizer; interferes with and reduces the production of major crops (Suryaningsih et al., 2011). The presence of weeds causes competition between weeds and plants to get the same growing medium where the amount is limited. The type and density of weeds is a factor causing competition. Depressed growth and low yields of major crops are caused by weeds which able to compete and secrete allelopathic substances that inhibit the growth of plants around them (Oksari, 2014).

Devkota and Jha (2010) research showed that there is an allelopathic effect of aqueous extracts of Parthenium hysterophorus, Chromolaena odorata, Ageratum conyzoides and Xanthium strumarium that significantly inhibiting $C$. asiatica seed germination. Several studies related to weeds are the dominant weeds in rubber plantations which included the families of Graminae, Compositae and Cyperaceae, while the dominant weeds in maize plantations are Asteraceae and Poaceae (Suryaningsih et al., 2011; Sari and Rahayu, 2013). Weeds are the most severe and widespread biological constraint on crop production and cause imperceptible damage until the crops are harvested. There is an inhibitory and stimulatory activity on the percentage of germination of seeds and growth of tomato seedlings (Ali et al., 2014). In sugarcane cultivation, the presence of weeds can reduce sugarcane weight production and sugarcane yield, therefore weed control needs to be done (Pariyanto et al., 2015).

The proper weeding regime for effective and economic weed management needs to be done to obtain high yields and profit. Weeding regime gives effect on rice plant height and yield (Khan et al., 2017). The age of young plants becomes a critical period because the influence of weeds is very visible. Efforts to control weeds must be implemented more intensively by pondering economic threshold factors. Weeding regime is primarily aimed at suppressing the growth of weeds to the limits of economic damage (Barus, 2003). Research conducted by Widayat and Purba (2015), Kilkoda et al. (2015) and Prayogo et al. (2017) on rice and soybean plants proved that weed control efforts can increase yields. Understanding the types of weeds that are common in planted areas and the factors that cause the emergence of these weeds is important as preventive efforts to control weeds. Other important information is related to the methods of reproduction, location of distribution and population dynamics of weeds. Weed diversity on agricultural land is largely influenced by climate and agroecological status.

In sustainable agriculture, farmers need to be aware of the life cycle of the weed species and have knowledge about when and what actions should be taken to control weeds on the cultivated site (Sims et al., 2018). In order to maintain sustainable agriculture, we need to improve knowledge regarding the agriculture system. Production system aspects need to be considered to do the soil management such as leveling field surface, choose the crops by the points of view of production residue, the depth of rooting system, soil nutrition, planning the weed control strategies and also assessing the required machinery (Sims et al., 2009).

Weed population in one region is different from other regions. The weed community pattern changes according to the influencing factors. The types of weeds in an area need to be known for the importance of managing weed vegetation that disturbs the main crops (Faisal et al., 2015). This research was conducted to identify the types of weeds found in centella plantations and to analyze it's vegetation, thereby it can be used as a basic reference in controlling weeds in centella cultivation.

\section{MATERIALS AND METHOD}

The research was conducted from October 2018 until May 2019 at the Center of Medicinal Plant and Traditional Medicine Research and Development's Field Station in Tohkuning Village, Karangpandan Sub-district, Karanganyar Regency, Central Java Province of Indonesia (7³6'39.6" South Latitude - $111^{\circ} 03^{\prime} 14.6^{\prime \prime}$ East Longitude) using a survey method and Integrated Laboratory.

This research was aimed to determine the weeds types and amount found in centella 
cultivation. Sampling was carried out in purposive manners based on the presence of weeds in the cultivation area. Weeds observation was carried out in linear methods on 12 plantation beds of centella, with a plot of $6 \mathrm{~m}^{2} \times 2 \mathrm{~m}^{2}$ in each as observation unit. Individual weed used in this research was collected in seedling level vegetation form which was intersected by the transect line. Individuals with unknown identities will be identified in the laboratory.

Weeds observations were made during weeding on one cropping season. Weeds observation was carried out by recording the number of species and number of individual weeds and taking documentation of weeds that were recorded for identification purposes.
The material used in this research was centella cultivation. The tools used in this study were manual counting tools, a camera, a photo mat and books for plant identification. The obtained plants were identified by comparing them with the plant identification book and inquires the experts. However, if it was not possible, they were only identified according to the genus. Identified plants grouped into weed groups using a weed identification book; Hand Book on Weed Identification.

For the estimated parameters were Density (D), Relative Density (RD), Frequency (F), Relative Frequency (RF), Importance Value Index (IVI) and Sum Dominance Ratio (SDR) with the following formulas:

$$
\begin{array}{ll}
\mathrm{D} & =\frac{\text { abundance of an individual species }}{\text { observation plot area }} \\
\mathrm{RD} & =\left(\frac{\text { density of an individual species }}{\text { density of all species }}\right) \times 100 \% \\
\mathrm{~F} & =\frac{\text { number of plots where a species found }}{\text { number of total observation plots }} \\
\mathrm{RF} & =\left(\frac{\text { frequency of an individual species }}{\text { frequency of all species }}\right) \times 100 \% \\
\mathrm{IVI} & \quad \mathrm{RD}+\mathrm{RF}(\text { Gunawan et al., } 2011) \\
\mathrm{SDR} & =\frac{\mathrm{IVI}}{2}(\text { Dahang, 2018) }
\end{array}
$$$$
\text { Diversity index }\left(H^{\prime}\right)=-\sum\left(\left(\frac{\text { abundance of the } \mathrm{i} \text {-th species }}{\text { abundance of total species }}\right) x \ln \left(\frac{\text { abundance of the } \mathrm{i}-\text { th species }}{\text { abundance of total species }}\right)\right)
$$$$
\text { (Mariana and Warso, 2016) }
$$

$\mathrm{D}$ is the number of individuals per unit area or per unit volume. RD is the ratio of one type of vegetation density to all vegetation types densities in an area. $\mathrm{F}$ is a value that indicates the spread of a vegetation type in a number of sample plots under study. RF is the percentage ratio between the frequency of a vegetation type with the frequency of all vegetation types in the area. IVI shows the ecological importance of a plant species and shows its role in a community so that it is known to be influential or not. SDR is the level of dominance of species in a plant community. H' (Shanon-Weiner index) is an index that shows the level of environmental stability in the conditions of interaction between species in the environment (Aditama and Kurniawan, 2013).

\section{RESULTS AND DISCUSSION}

Weeds are plants that grow around cultivated plants that can inhibit the growth of Centella plants. The presence of weeds causes competition between weeds and cultivated plants for available soil nutrients. This research needs to be done as a basic reference in weed control in Centella cultivation. Based on the identification results, 35 weed species were found in centella plantations. The identified weeds in centella plantations belong to 20 plant families, while the two species have not been identified (Table 1). 
Table 1. Weeds species found in centella plantations in Tohkuning Village, Karangpandan Sub-district, Karanganyar Regency

\begin{tabular}{|c|c|c|c|c|}
\hline No. & Plant family & No. & Species name & $\begin{array}{l}\text { Number of } \\
\text { individuals }\end{array}$ \\
\hline 1. & Achantaceae & 1. & Ruellia napifera Zoll. and Moritzi (Unresolved name) & 2 \\
\hline \multirow[t]{2}{*}{2.} & Amaranthaceae & 2. & Alternanthera philoxeroides (Mart.) Griseb. & 99 \\
\hline & & 3. & Amaranthus hybridus L. & 9 \\
\hline 3. & Araceae & 4. & Amorphophallus paeoniifolius (Dennst.) Nicolson & 1 \\
\hline \multirow[t]{2}{*}{4.} & Brassicaceae & 5. & Rorippa indica (L.) Hiern & 13 \\
\hline & & 6. & Cardamine flexuosa With & 2 \\
\hline 5. & Caricaceae & 7. & Carica papaya $\mathrm{L}$. & 1 \\
\hline 6. & Caryophyllaceae & 8. & Drymaria cordata (L.) Willd. ex Schull. & 1 \\
\hline 7. & Cleomaceae & 9. & Cleome rutidosperma D.C. & 43 \\
\hline 8. & Commelinaceae & 10. & Commelina diffusa Burm. f. & 26 \\
\hline \multirow[t]{7}{*}{9.} & Compositae & 11. & Eclipta prostrata (L.) L. & 145 \\
\hline & & 12. & Emilia sonchifolia (L.) DC. ex DC. & 51 \\
\hline & & 13. & Ageratum conyzoides (L.) L. & 34 \\
\hline & & 14. & Crassocephalum crepidioides (Benth.) S. Moore & 8 \\
\hline & & 15. & Sonchus arvensis L. & 3 \\
\hline & & 16. & Erigeron sumatrensis Retz & 2 \\
\hline & & 17. & Acmella paniculata (Wall. ex DC.) R.K. Jansen & 1 \\
\hline 10. & Convolvulaceae & 18. & Ipomoea sp. & 1 \\
\hline 11. & Cyperaceae & 19. & Cyperus rotundus $\mathrm{L}$. & 864 \\
\hline 12. & Euphorbiaceae & 20. & Euphorbia hirta L. & 10 \\
\hline \multirow[t]{3}{*}{13.} & Leguminosae & 21. & Centrosema virginianum (L.) Benth. & 1 \\
\hline & & 22. & Desmodium canadense (L.) DC. & 1 \\
\hline & & 23. & Mimosa pudica $\mathrm{L}$. & 1 \\
\hline 14. & Linderniaceae & 24. & Lindernia sp. & 1 \\
\hline \multirow[t]{2}{*}{15.} & Malvaceae & 25. & Hibiscus sabdariffa L. & 6 \\
\hline & & 26. & Sida alnifolia $\mathrm{L}$. & 1 \\
\hline 16. & Oxalidaceae & 27. & Oxalis corniculata $\mathrm{L}$. & 4 \\
\hline \multirow[t]{2}{*}{17.} & Phyllanthaceae & 28. & Phyllanthus niruri $\mathrm{L}$. & 247 \\
\hline & & 29. & Phyllanthus debilis Klein ex Willd. & 7 \\
\hline \multirow[t]{2}{*}{18.} & Poaceae & 30. & Eleusine indica (L.) Gaertn & 10 \\
\hline & & 31. & Cynodon dactylon (L.) Pers. & 3 \\
\hline 19. & Portulacaeae & 32. & Portulaca oleracea L. & 89 \\
\hline 20. & Rubiaceae & 33. & Oldenlandia corymbosa $\mathrm{L}$. & 123 \\
\hline \multirow[t]{2}{*}{21.} & Unidentified & 34. & Species 1 & 1 \\
\hline & & 35. & Species 2 & 1 \\
\hline
\end{tabular}

The highest percentage of weed species was found in Compositae family by $20 \%$. In addition to Compositae, weed species from the Leguminosae family are also considerably large at $8.57 \%$ (Figure 1). The highest number of individual weeds was found in the Cyperus rotundus L. plant species, as much as 864 individuals. Several other species of weeds have quite a number namely Alternanthera philoxeroides (Mart.) Griseb. (99 individuals), Eclipta prostrata (L.) L (145 individuals), Oldenlandia corymbosa L. (123 individuals) and Phyllanthus niruri L. (247 individuals) (Table 1).

From the 25 species of weeds found in centella plantations, about $51.43 \%$ of weeds only have the number of individuals below 5, namely Acmella paniculata (Wall. ex DC.) R.K. Jansen, Amorphophallus paeoniifolius (Dennst.) Nicolson, Cardamine flexuosa With., Carica papaya L., Centrosema virginianum (L.) Benth., Cynodon dactylon (L.) Pers., Desmodium canadense (L.) DC., Drymaria cordata (L.) Willd. ex Schull., Erigeron sumatrensis Retz., 
Ipomoea sp., Lindernia sp., Mimosa pudica L., Oxalis corniculata L., Ruellia napifera Zoll. and
Moritzi (unresolved name) and Sida alnifolia L. (Table 1).

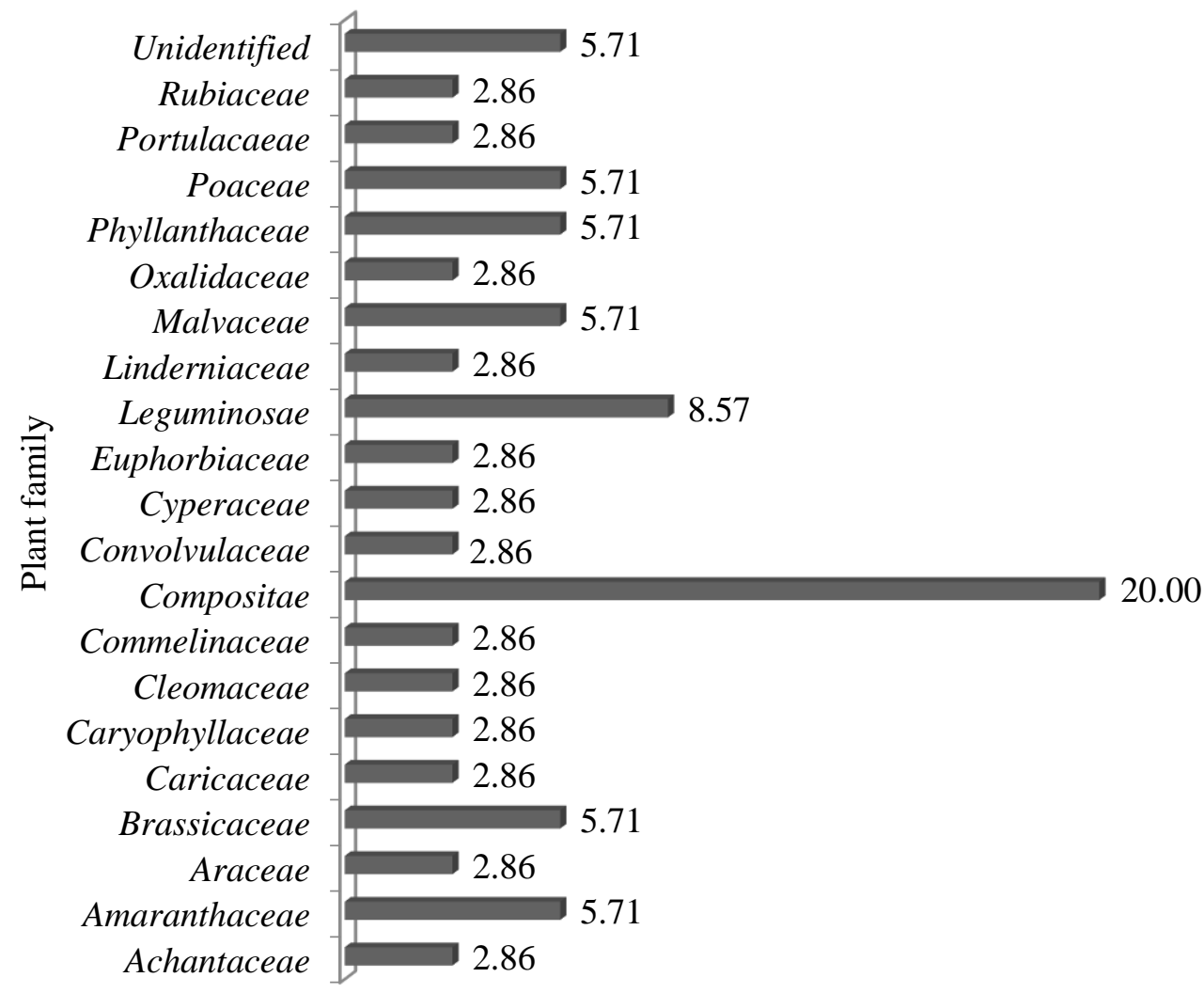

Figure 1. Percentage (\%) of weed families in centella plantations

Based on their morphological characteristics, the weeds are classified into 4 groups, namely narrow-leaf weeds (grasses) which include Poaceae; nutgrass (sedges) which include Cyperaceae; broad leaf weeds include families other than Poaceae and Cyperaceae; and ferns
(Barus, 2003). In centella plantations, identified weeds are divided into three groups, that is broad leaves, grasses and sedges. The majority of weeds found in broad leaves group by $90.91 \%$ (30 species) in centella plantations (Figure 2).

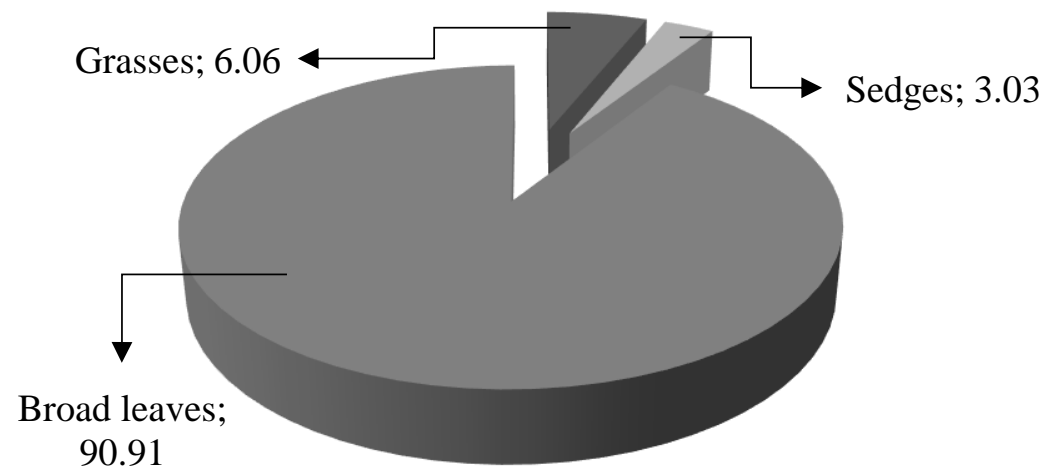

Figure 2. Percentage (\%) of centella plantations weed groups based on morphological characteristics

Five weeds with the highest number of individuals belong to the sedges group (Cyperus rotundus L.) and broad leaves (Alternanthera philoxeroides (Mart.) Griseb., Eclipta prostrata (L.) L., Oldenlandia corymbosa L. and Phyllanthus niruri L. (Figure 3). 


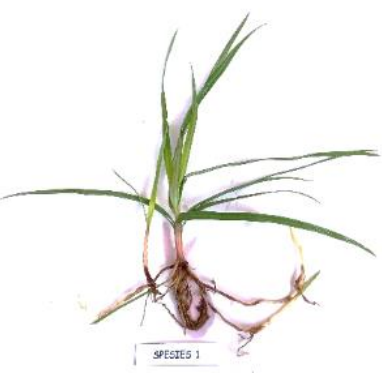

Cyperus rotundus $\mathrm{L}$.

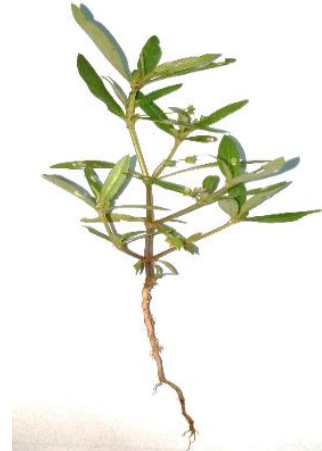

Hedyotis corymbosa $\mathrm{L}$.

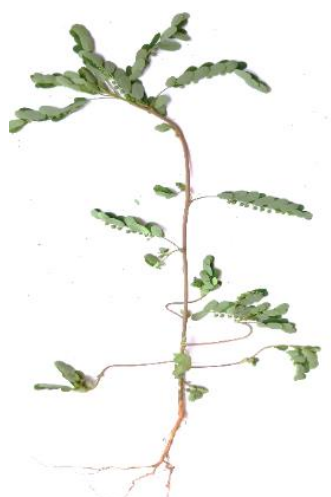

Phyllanthus niruri L.

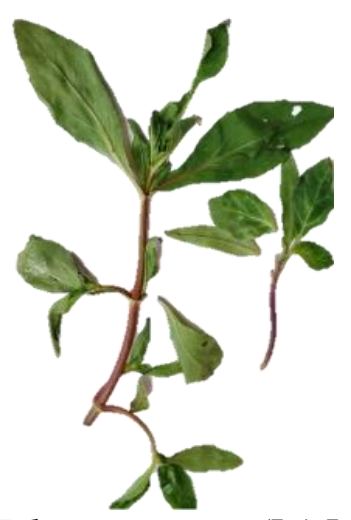

Eclipta prostrata (L.) L.

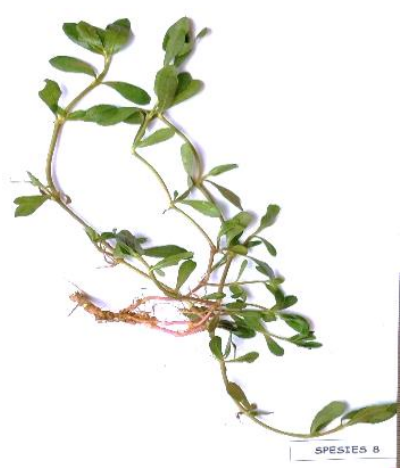

Alternanthera philoxeroides (Mart.) Griseb.

Figure 3. Five dominant weeds in centella plantations

Alternanthera philoxeroides (Mart.) Griseb.

Annual creeping herb with prostrate growth. Prostrate, annual creeping herb. Stem with long crisped hairs on the younger parts. Leaf blade is inverted-lance shaped or spatula shaped, $1.5-2.0 \mathrm{~cm}$ long and $0.3-0.5 \mathrm{~cm}$ wide, tip obtuse to rounded. Stalkless flower-heads are ovoid to spherical, often hairy at base with white papery flowers. Fruit utricle orbicular. Seed discoid, $1 \mathrm{~mm}$ across and fairly reticulate (Naidu, 2012). A. philoxeroides is a weed on sugarcane (Hariri and Irsyam, 2019).

\section{Cyperus rotundus $\mathrm{L}$.}

A perennial sedge, known as purple nutsedge (Monaco et al., 2002). The stem is hard, fragrant, globose-ovoid tubers, up to $1.2 \mathrm{~cm}$ long and $0.3-0.7 \mathrm{~cm}$ in diameter. Culms grew solitary or few together, sparsely tufted, erect, $10-75 \mathrm{~cm}$ tall, 3-angled at top. Leaves are narrowly linear, shorter or longer than stem, $0.4-0.8 \mathrm{~cm}$ wide, dark green above, pale beneath. Inflorescence a simple or compound umbel, rays 2-8, each up to $7.5 \mathrm{~cm}$ long, bearing short spikes of 3-10 spreading, red-brown spikelet. Cyperus rotundus L. oblong to ovate- oblong, maturing brown, 3-sided, 1.3-1.5 mm long and 0.5-0.7 mm wide (Naidu, 2012). C. rotundus is one of the weeds in soybean and tomatoes cultivation (Ali et al., 2014; Imaniasita et al., 2020).

\section{Eclipta prostrata (L.) L.}

Erect stem up to $15-50 \mathrm{~cm}$ tall, ascending or basal prostrate, strigose-pilose, branched at base or above, nodes rooting while touching ground. Stem color is green or reddish brown, sparsely coarse hairy. Leaves opposite, $3-10 \mathrm{~cm}$ long and $0.5-2.0 \mathrm{~cm}$ wide. Leaves blades elliptical lanceolate or linear-lanceolate, apex gradually acuminate, base cuneate gradually narrow, densely strigose-pubescent on both surface. Petiolate is sessile or short. Flower with 1-2 capitula, terminal or auxiliary, ovate, $5-10 \mathrm{~mm}$ in diameter. Ray florets ligulate, whitish, lamina 2.5-3.0 mm long, $0.4 \mathrm{~mm}$ wide, apex bifid or entire, female and fertile. Achenes developing from tubular flowers flatly 4 ribbed, $2.8 \mathrm{~mm}$ long, 1.5 wide and margin ribbed. Dark brown seed with truncate apex, 2.5-3.0 mm. Main root inconspicuous, branched, numerous fibrous roots (Xu and Chang, 2017). E. prostrata 
is one of the weeds in corn cultivation (Budi, 2018).

\section{Oldenlandia corymbosa $\mathbf{L}$.}

An annual herb with ascending or erect stem 4 angled. Leaves are linear-oblong or narrowly elliptic, almost stalkless, 1.0-3.5 cm long and 1.5$7.0 \mathrm{~mm}$ wide. Midrib of the leaf is prominently visible. White or faintly pinkish-purplish flower, on slender stalks $4-8 \mathrm{~mm}$ long. Fruit have the shape of capsule is about $2 \mathrm{~mm}$ x $2 \mathrm{~mm}$, flattened at apex, slightly laterally compressed (Naidu, 2012). This plant is one of the weeds in corn cultivation (Suryaningsih et al., 2011).

\section{Phyllanthus niruri $\mathrm{L}$}

A small, erect, annual herb that grows up to $30-40 \mathrm{~cm}$ in height. The stem is quite glabrous, stem often branched at the base, leaf bearing branchlets slender and spreading. The bark is smooth and light green. The leaves are numerous, subsessile and distichous. The flowers are small, white to light yellowish. Male flowers in axillary, females in solitary. Fruit form a capsule depressed-globose and smooth scarcely lobed. Seed trigonous and rounded (Naidu, 2012). $P$. niruri is one of the weeds in rice cultivation (Syarifah et al., 2018).

Table 2. Weeds species and vegetation (frequency and density) composition in centella plantation

\begin{tabular}{|c|c|c|c|c|c|}
\hline No. & Species name & $\mathrm{RD}(\%)$ & $\mathrm{RF}(\%)$ & $\operatorname{SDR}(\%)$ & IVI (\%) \\
\hline 1. & Ageratum conyzoides L. & 1.88 & 4.20 & 3.04 & 6.07 \\
\hline 2. & Alternanthera philoxeroides (Mart.) Griseb. & 5.46 & 5.59 & 5.53 & 11.06 \\
\hline 3. & Amaranthus hybridus L. & 0.50 & 2.10 & 1.30 & 2.59 \\
\hline 4. & Amorphophallus paeoniifolius (Dennst.) Nicolson & 0.06 & 0.70 & 0.38 & 0.75 \\
\hline 5. & Cardamine flexuosa $\mathrm{L}$. & 0.11 & 0.70 & 0.40 & 0.81 \\
\hline 6. & Carica papaya $\mathrm{L}$. & 0.06 & 0.70 & 0.38 & 0.75 \\
\hline 7. & Centrosema virginianum (L.) Benth. & 0.06 & 0.70 & 0.38 & 0.75 \\
\hline 8. & Cleome rutidosperma D.C. & 2.37 & 7.69 & 5.03 & 10.07 \\
\hline 9. & Commelina diffusa Burm. $\mathrm{f}$. & 1.43 & 2.80 & 2.12 & 4.23 \\
\hline 10. & Crassocephalum crepidioides (Benth.) S.Moore & 0.44 & 5.59 & 3.02 & 6.04 \\
\hline 11. & Cyperus rotundus $\mathbf{L}$. & 47.68 & 8.39 & 28.04 & 56.07 \\
\hline 12. & Cynodon dactylon (L.) Pers. & 0.17 & 1.40 & 0.78 & 1.56 \\
\hline 13. & Desmodium canadense (L.) DC. & 0.06 & 0.70 & 0.38 & 0.75 \\
\hline 14. & Drymaria cordata (L.) Willd. and Schull. & 0.06 & 0.70 & 0.38 & 0.75 \\
\hline 15. & Eclipta prostrata $\mathrm{L}$. & 8.00 & 8.39 & 8.20 & 16.39 \\
\hline 16. & Eleusine indica (L.) Gaertn & 0.55 & 2.10 & 1.32 & 2.65 \\
\hline 17. & Emilia sonchifolia (L.) D.C ex Wight & 2.81 & 4.90 & 3.85 & 7.71 \\
\hline 18. & Erigeron sumatrensis Retz & 0.11 & 1.40 & 0.75 & 1.51 \\
\hline 19. & Euphorbia hirta L. & 0.55 & 2.10 & 1.32 & 2.65 \\
\hline 20. & Hibiscus sabdariffa $\mathrm{L}$. & 0.33 & 2.10 & 1.21 & 2.43 \\
\hline 21. & Hydeotis corymbosa $\mathrm{L}$. & 6.79 & 6.29 & 6.54 & 13.08 \\
\hline 22. & Ipomoea sp. & 0.06 & 0.70 & 0.38 & 0.75 \\
\hline 23. & Lindernia sp. & 0.06 & 0.70 & 0.38 & 0.75 \\
\hline 24. & Mimosa pudica L. & 0.06 & 0.70 & 0.38 & 0.75 \\
\hline 25. & Oxalis corniculata $\mathrm{L}$. & 0.22 & 2.80 & 1.51 & 3.02 \\
\hline 26. & Phyllanthus debilis Klein ex Willd. & 0.39 & 2.80 & 1.59 & 3.18 \\
\hline 27. & Phyllanthus niruri $\mathrm{L}$. & 13.63 & 8.39 & 11.01 & 22.02 \\
\hline 28. & Portulaca oleracea L. & 4.91 & 4.20 & 4.55 & 9.11 \\
\hline 29. & Rorippa indica $\mathrm{L}$. & 0.72 & 4.90 & 2.81 & 5.61 \\
\hline 30. & Ruellia napifera Zoll. \& Moritzi & 0.11 & 1.40 & 0.75 & 1.51 \\
\hline 31. & Sida alnifolia $L$. & 0.06 & 0.70 & 0.38 & 0.75 \\
\hline 32. & Sonchus arvensis L. & 0.17 & 1.40 & 0.78 & 1.56 \\
\hline 33. & Spilanthes paniculataWall. ex DC. & 0.06 & 0.70 & 0.38 & 0.75 \\
\hline 34. & Unidentified & 0.06 & 0.70 & 0.38 & 0.75 \\
\hline 35. & Unidentified & 0.06 & 0.70 & 0.38 & 0.75 \\
\hline & $\mathrm{H}^{\prime}$ & \multicolumn{4}{|c|}{1.93} \\
\hline
\end{tabular}


In general, the weed that dominates is viewed from the number of individuals compared to other types. The dominant weed in centella cultivation was Cyperus rotundus L. with the highest RD, SDR and the IVI compared to 34 other species. The highest RF was found in C. rotundus L., E. prostrata (L.) L. and P. niruri L. weeds at the same value $8.39 \%$ (Table 2).

\section{Density}

Weed density in centella plantations is in a low category based on the vegetation density category in the research of Hidayat et al. (2017), namely above $12 \%$ and below 50\%. Cyperus rotundus L. had the highest density level compared to other weed species (Table 2).

\section{Frequency}

Overall, the presence of a weed species in centella plantations, based on the RF classification according to research conducted by Hidayat et al. (2017) and Sari et al. (2018), was included in the very low category, which was between $1-20 \%$ (class A). The highest RF values obtained in $C$. rotundus L., E. prostrata L. and $P$. niruri L. showed that these three types were often found in every observation plot (Table 2).

\section{Dominance}

Cyperus rotundus L. was dominating in centella plantations because it has very high dominance value compared with other weeds, namely $28.04 \%$. Phyllanthus niruri L. was ranked in the second position in centella cropping right after $C$. rotundus $\mathrm{L}$. The lowest dominance was occupied by several weeds $(0.38 \%)$ (Table 1$)$.

\section{Importance Value Index}

The high value of the IVI greatly affects plant communities. The IVI value was described as the influence level of a weed on the environmental ecosystem stability (Hidayat et al., 2017). The IVI categorization of weeds in centella plants was based on criteria according to Hidayat et al. (2017), C. rotundus L. occupied a high IVI category $(56.07 \%), P$. niruri L. had an IVI of the medium category and other weeds were in a low category (Table 2). In centella cropping, $C$. rotundus L. has an important role in the plant community in the planting environment.

\section{Diversity Index}

Based on $\mathrm{H}^{\prime}$ criteria in Novelinda et al. research (2014), the $\mathrm{H}^{\prime}$ of centella plantations (1.93) (Table 2) showed that the weeds diversity in centella plantation is at a moderate level. The high and low diversity of organisms in an ecosystem depends on the number of individuals present. The diversity of vegetation in an area is strongly influenced by environmental conditions. Extreme conditions can disturb the stability of life and plant distribution. High species diversity has a role to be an indicator of a growing environment constancy or stability. The high environmental stability shows a high complexity of composing composition with high interaction between the constituents of the environment, which increases the ability of the environment to encounter disturbances (Oksari, 2014).

In centella plantation, $C$. rotundus $\mathrm{L}$. weed was mostly found because it has high adaptability to various main crops. Cyperus rotundus $\mathrm{L}$. is classified as a ferocious weed because it can grow in extreme environmental conditions. It also can grow in various types of soil, high temperatures and has broad adaptability to grow and thrive in environments with limiting factors (Pranasari et al., 2012). Cyperus rotundus L. is categorized as a dangerous weed which is classified as a noxious weed because it has a detrimental effect on staple crops if it is not controlled properly (Budi, 2018). Cyperus rotundus $\mathrm{L}$. can take control of the growing space and can compete with the growth of the main plant. This weed is a perennial plant with a wide distribution, long root systems that form complex networks in the soil and reproduce by seed (Perdana et al., 2013; Perianto et al., 2016). Even research conducted by Cirujeda et al. (2012) states that $C$. rotundus $\mathrm{L}$. is considered a serious weed because it can penetrate polyethylene (PE) mulch plastic which is commonly used in horticultural crops. Also, C. rotundus L. belonging to the $\mathrm{C} 4$ group has a high light compensation point compared to broadleaf weeds which are mostly included in the group (Marsal et al., 2015).

Aside from being the light, water and nutrients fulfillment competitor, the presence of allelopathic substances released by $C$. rotundus L. also interfering plant growth (Cirujeda et al., 2012; Faisal et al., 2015). The allelochemicals released by the puzzles travel to the target organism by roots exudation. It suppresses the growth and production of cultivated plants and also the growth of other weeds (Andhini and Chozin, 2016; Dewi et al., 2017; Siregar et al., 2017). 
In a sustainable medicinal plants cultivation, Cyperus rotundus $\mathrm{L}$. weeds management can be carried out by intercropping arrangement to reduce the intensity of sunlight reaching the soil, biodegradable mulches usage and planting medicinal plants that can suppress the growth of Cyperus rotundus L. (Cirujeda et al., 2012; Iqbal et al., 2019; Marí et al., 2020). Manual weed control can be done periodically. In addition, bioherbicides from 50\% clove extract and 50\% ketapang leaves can inhibit the growth of Cyperus rotundus L. (Riskitavani and Purwani, 2013; Talahatu and Papilaya, 2015). The oxyfluorfen and post-growth herbicide type glyphosate can be applied to the weeds of the type of puzzle (Widaryanto, 1994; Perkasa, 2016). Bioherbicides from $0.28 \%$ pine leaf extract can produce $6.92 \%$ phytotoxicity (Siregar and Nugroho, 2020).

\section{CONCLUSIONS}

The results of weed vegetation analysis on centella plantations in Tohkuning, Karangpandan showed that weed centella plantations identified as many as 35 species of weeds from 20 families. The weed that dominant in centella plantations is Cyperus rotundus $\mathrm{L}$. because it has allelochemical exudates and high adaptability. Sustainable centella cultivation by applying the proper weed control techniques by considering the living nature of Cyperus rotundus L. is necessary.

\section{ACKNOWLEDGMENTS}

We would like to thank Prof. Ir. Yuli Widiyastuti, M.P., Dyah Subositi, M.Sc. and Muhammad Bakti Samsu Adi, M.Sc. for giving input suggestion in conducting research and article updates. Thank you also goes to Ery Setyo Hartanto, A.Md. and Tohkuning Medicinal Research Station workers who assisted the research.

\section{REFERENCES}

Aditama, R. C., \& Kurniawan, N. (2013). Struktur komunitas serangga nokturnal areal pertanian padi organik pada musim penghujan di Kecamatan Lawang, Kabupaten Malang. Jurnal Biotropika, 1(4), 186-190. Retrieved from https://biotropika.ub.ac.id/index.php/bio tropika/article/view/177

Ali, D., Ahmad, A., \& Mohsen, N. (2014). Determination of allelopathic effect of purple nutsedge (Cyperus rotundus) on germination and initial development of tomato (Lycopersicum esculentum). Indian Journal of Fundamental and Applied Life Sciences, 4(2), 576-580. Retrieved from https://www.cab direct.org/cabdirect/abstract/20143278902

Andhini, M., \& Chozin, M. (2016). Keefektifan allelopati teki (Cyperus rotundus L.) terhadap penekanan perkecambahan biji Asytasia gangetica (L.) T. Anderson pada berbagai jenis tanah. Buletin Agrohorti, 4(2), 180-186. https://doi.org/10.29244/agrob.v4i2.15018

Barus, E. (2003). Pengendalian gulma di perkebunan, efektivitas dan efisiensi aplikasi herbisida (5th ed.). Yogyakarta: Kanisius. Retrieved from https://books.google.co.id/ books?id=0tDfDwAAQBAJ \&pg $=$ PA38\&dq= Pengendalian+gulma+di+perkebunan,+efekti vitas+dan+efisiensi+aplikasi+herbisida\&hl=e $\mathrm{n} \& \mathrm{sa}=\mathrm{X} \& \mathrm{ved}=2 \mathrm{ahUKEwiv0IGNmfHtAhVV}$ xzgGHWOXAooQ6AEwAHoECAQQAg\#v= onepage $\& \mathrm{q}=$ Pengendalian $\% 20$ gulma $\% 20 \mathrm{di} \%$ 20perkebunan $\% 2 \mathrm{C} \% 20$ efektivitas $\% 20$ dan $\% 2$ 0efisiensi\%20aplikasi\%20herbisida $\& \mathrm{f}=$ false

Budi, G. P. (2018). Analisis vegetasi dan penentuan dominansi gulma pada pertanaman jagung di beberapa ketinggian tempat. Agritech, 20(1), 13-18. Retrieved from http://jurnalnasional.ump.ac.id/index.php/AG RITECH/article/view/3417

Cirujeda, A., Anzalone, A., Aibar, J., Moreno, M. M., \& Zaragoza, C. (2012). Purple nutsedge (Cyperus rotundus L.) control with paper mulch in processing tomato. Crop Protection, 39, 66-71. https://doi.org/10.1016/j.cropro. 2012.03.028

Dahang, D. (2018). Analisis vegetasi gulma pada ladang broccoli (Brassica oleraceae var.italica 1) di kebun pendidikan Universitas Quality Berastagi. Jurnal Agroteknosains, 2(2), 222229. Retrieved from http://www.portaluni versitasquality.ac.id:5388/ojssystem/index.ph p/AGROTEKNOSAINS/article/view/147

Devkota, A., \& Jha, P. K. (2010). Seed germination responses of the medicinal herb Centella asiatica. Brazilian Journal of Plant Physiology, 22(1), 143-150. https://doi.org/ 10.1590/S1677-04202010000200008

Dewi, S. A., Chozin, M. A., \& Guntoro, D. 
(2017). Identifikasi senyawa fenol beberapa aksesi teki (Cyperus rotundus L.) serta pengaruhnya terhadap perkecambahan biji Borreria alata (Aubl.) DC. Jurnal Agronomi Indonesia, 45(1), 93-99. https://doi.org/ 10.24831/jai.v45i1.12730

Faisal, R., Siregar, E. B. M., \& Anna, N. (2015). Inventarisasi gulma pada tegakan tanaman muda Eucalyptus spp. Peronema Forestry Science Journal, 2(2), 44-49. Retrieved fro https://jurnal.usu.ac.id/index.php/PFSJ/article/ view/3525

Gunawan, W., Basuni, S., Indrawan, A., Prasetyo, L. B. \& Soedjito, H. (2011). Analisis komposisi dan struktur vegetasi terhadap upaya restorasi kawasan hutan Taman Nasional Gunung Gede Pangrango. Jurnal Pengelolaan Sumberdaya Alam dan Lingkungan, 1(2), 93-105. Retrieved from https://journal.ipb.ac.id/index.php/jpsl/article/ view/10821

Hariri, M. R., \& Irsyam, A. S. D. (2019). Jenisjenis gulma pada kebun tebu di Kecamatan Asembagus, Situbondo, Jawa Timur: Kelompok Eudikotiledon. Jurnal Riset Biologi Dan Aplikasinya, 1(2), 47-53. http://dx. doi.org/10.26740/jrba.v1n2.p47-53

Hashim, P. (2011). Mini Review: Centella asiatica in food and beverage applications and its potential antioxidant and neuroprotective effect. International Food Research Journal, 18(4), 1215-1222. Retrieved from http://www. myjurnal.my/public/article-view.php?id=9070

Hidayat, M., Laiyanah, Silvia, N., Putri, Y. A., \& Marhamah, N. (2017). Analisis vegetasi tumbuhan menggunakan metode transek garis (line transek) di hutan Seulawah Agam Desa Pulo Kemukiman Lamteuba Kabupaten Aceh Besar. Prosiding Seminar Nasional Biotik, 4(1), 85-91. Retrieved from https://jurnal.arraniry.ac.id/index.php/PBiotik/article/view/21 98

Imaniasita, V., Liana, T., Krisyetno, \& Pamungkas, D. S. (2020). Identifikasi keragaman dan dominansi gulma pada lahan pertanaman kedelai. Agrotechnology Research Journal, 4(1), 11-16. https://doi.org/10.20961/ agrotechresj.v4i1.36449
Iqbal, J., Ditommaso, A., Rehmani, M. I. A., Jabran, K., Hussain, S., Nasim, W., Fahad, S., Shehzad, M. A., \& Ali, A. (2019). Purple nutsedge (Cyperus rotundus) control through interference by summer crops. International Journal of Agriculture \& Biology, 21(5), 1083-1088. Retrieved from http://www.fs publishers.org/published_papers/88056_23\% 20doi\%2015.0997\%20IJAB-16-0569\%20(6) \%201083-1088.pdf

Jahan, R., Hossain, S., Seraj, S., Nasrin, D., Khatun, Z., Das, P. R., Islam, M. T., Ahmed, I., \& Rahmatullah, M. (2012). Centella asiatica (L.) Urb.: Ethnomedicinal uses and their scientific validations. AmericanEurasian Journal of Sustainable Agriculture, 6(4), 261-270. Retrieved from http://www. aensiweb.net/AENSIWEB/aejsa/aejsa/2012/2 61-270.pdf

Januwati, M., Sudiatso, S., \& Andriani, S. W. (2002). Pengaruh dosis pupuk kandang dan tingkat populasi terhadap pertumbuhan dan produksi pegagan (Centella asiatica (L.) Urban) di bawah tegakan kelapa (Cocos nucifera L.). Jurnal Bahan Alam Indonesia, 1(2), 49-57. Retrieved from https://scholar. google.com/scholar?cluster $=17520456284650$ 558011\&hl=en\&oi=scholarr

Khan, M. Z. K., Hasan, A. K., Anwar, M. P., \& Islam, M. S. (2017). Weeding regime and plant spacing influence on weed growth and performance of transplant aman rice variety Binadhan- 7. Fundamental and Applied Agriculture, 2(3), 331-339. https://doi.org/ 10.5455/faa. 281436

Kilkoda, A. K., Nurmala, T., \& Widayat, D. (2015). Pengaruh keberadaan gulma (Ageratum conyzoides dan Boreria alata) terhadap pertumbuhan dan hasil tiga ukuran varietas kedelai (Glycine max L. Merr) pada percobaan pot bertingkat. Jurnal Kultivasi, 14(2), 1-9. https://doi.org/10.24198/kultivasi. v14i2.12072

Marí, A. I., Pardo, G., Aibar, J., \& Cirujeda, A. (2020). Purple nutsedge (Cyperus rotundus L.) control with biodegradable mulches and its effect on fresh pepper production. Scientia Horticulturae, 263, 109111. https://doi.org/ 10.1016/j.scienta.2019.109111 
Mariana, \& Warso, F. W. (2016). Analisis komposisi dan struktur vegetasi untuk menentukan indeks keanekaragaman di kawasan hutan kota Pekanbaru. Bio-Lectura: Jurnal Perndidikan Biologi, 3(2), 90-96. https://doi.org/10.31849/bl.v3i2.339

Marsal, D., Wicaksono, K. P., \& Widaryanto, E. (2015). Dinamika perubahan komposisi gulma pada tanaman tebu keprasan di lahan sistem reynoso dan tegalan. Jurnal Produksi Tanaman, 3(1), 81-90. Retrieved from http:// protan.studentjournal.ub.ac.id/index.php/prota n/article/view/172

Menkes RI. (2013). Peraturan Menteri Kesehatan Republik Indonesia No. 88 Tahun 2013. Rencana induk pengembangan bahan baku obat tradisional. Retrieved from https://m. hukumonline.com/pusatdata/detail/lt53ce3881 092c1/node/lt50ed19c5aced0/peraturan-mente ri-kesehatan-no-88-tahun-2013-rencana-induk -pengembangan-bahan-baku-obat-tradisional

Monaco, T. J., Weller, S. C., \& Ashton, F. M. (2002). Weed science: Principles and practices, 4th Edition. New York: John Wiley \& Sons, Inc.

Naidu, V. S. G. R. (2012). Hand Book on Weed Identification. Jabalpur, India: Directorate of Weed Science Research. Retrieved from https://krishi.icar.gov.in/jspui/handle/1234567 $89 / 5474$

Novalinda, R., Syam, Z., \& Solfiyeni. (2014). Analisis Vegetasi Gulma Pada Perkebunan Karet (Hevea brasiliensis Mull. Arg.) di Kecamatan Batang Kapas, Kabupaten Pesisir Selatan. Jurnal Biologi Universitas Andalas, 3(2), 129-134. Retrieved from http://jbioua. fmipa.unand.ac.id/index.php/jbioua/article/vie w/107

Oksari, A. A. (2014). Analisis vegetasi gulma pada pertanaman jagung dan hubungannya dengan pengendalian gulma di Lambung Bukit, Padang, Sumatera Barat. Jurnal Sains Natural Universitas Nusa Bangsa, 4(2), 135142. Retrieved from http://ejournalunb.ac.id/ index.php/JSN/article/view/85

Pariyanto, A., Sembodo, D. R. J., \& Sugiatno. (2015). Efikasi herbisida Flumioxazin pada gulma pertanaman tebu (Saccharum officinarum L.) lahan kering keprasan 1.
Jurnal Agrotek Tropika, 3(1), 99-105. Retrieved from https://jurnal.fp.unila.ac.id/ index.php/JA/article/view/1969

Perdana, E. O., Chairul, \& Syam, Z. (2013). Analisis vegetasi gulma pada tanaman buah naga merah (Hylocereus polyrhizus, L.) di Kecamatan Batang Anai, Kabupaten Padang Pariaman, Sumatera Barat. Jurnal Biologi Universitas Andalas, 2(4), 242-248. Retrieved from http://jbioua.fmipa.unand.ac.id/index.ph p/jbioua/article/view/69

Perianto, L. H., Soejono, A. T., \& Astuti, Y. T. M. (2016). Komposisi gulma pada lahan kelapa sawit (Elaeis guineensis Jacq.) pada tanaman belum menghasilkan dan tanaman menghasilkan di KP2 Ungaran. Jurnal Agromast, 1(2), 1-13. Retrieved from http:// scholar.googleusercontent.com/scholar? $\mathrm{q}=\mathrm{cac}$ he:8-itc9o3QCEJ:scholar.google.com/\&hl=en \&as_sdt $=0,5$

Perkasa, A. Y., Ghulamahdi, M., \& Guntoro, D. (2016). Penggunaan herbisida untuk pengendalian gulma pada budi daya kedelai jenuh air di lahan pasang surut. Jurnal Penelitian Pertanian Tanaman Pangan, 35(1), 63-70. https://doi.org/10.21082/jpptp.v35n1. 2016.p63-70

Pranasari, R. A., Nurhidayati, T., \& Purwani, K. I. (2012). Persaingan tanaman jagung (Zea mays) dan rumput teki (Cyperus rotundus) pada pengaruh cekaman garam (NaCl). Jurnal Sains Dan Seni ITS, 1(1), E54-E57. Retrieved from http://ejurnal.its.ac. id/index.php/sains_seni/article/view/910

Prayogo, D. P., Thamrin, H., \& Nugroho, A. (2017). Pengaruh pengendalian gulma pada pertumbuhan dan hasil tanaman kedelai (Glycine max (L.) Merril) pada berbagai sistem olah tanah. Jurnal Produksi Tanaman, 5(1), 24-32. Retrieved from http://protan.student journal.ub.ac.id/index.php/protan/article/view 1347

Riskitavani, D. V., \& Purwani, K. I. (2013). Studi potensi bioherbisida ekstrak daun ketapang (Terminalia catappa) terhadap gulma rumput teki (Cyperus rotundus). Jurnal Sains dan Seni ITS, 2(2), E59-E63. Retrieved from http:// ejurnal.its.ac.id/index.php/sains_seni/article/v iew/3593 
Sari, B. H., \& Diana, V. E. (2017). Formulasi ekstrak daun pegagan (Centella asiatica) sebagai sediaan sabun cair. Jurnal Dunia Farmasi, 2(1), 40-49. https://doi.org/10.33085 /jdf.v2i1.4395

Sari, D. N., Wijaya, F., Mardana, M. A., \& Hidayat, M. (2018). Analisis vegetasi tumbuhan bawah dengan metode transek (line transect) di kawasan hutan Deudap Pulo Aceh Kabupaten Aceh Besar. Prosiding Seminar Nasional Biotik, 5(1), 165-173. Retrieved from https://jurnal.ar-raniry.ac.id/index.php/ PBiotik/article/view/4253

Sari, H. F. M., \& Rahayu, S. S. B. (2013). Jenisjenis gulma yang ditemukan di perkebunan karet (Hevea brasiliensis Roxb.) Desa Rimbo Datar Kabupaten 50 Kota Sumatera Barat. Biogenesis: Jurnal Ilmiah Biologi, 1(1), 28 32. https://doi.org/10.24252/bio.v1i1.444

Seevaratnam, V., Banumathi, P., Premalatha, M. R., Sundaram, S. P., \& Arumugam, T. (2012). Functional properties of Centella asiatica (L.): A review. International Journal of Pharmacy and Pharmaceutical Sciences, 4(SUPPL. 5), 8-14. Retrieved from https:// www.researchgate.net/publication/286360480 _Functional_properties_of_Centella_asiatica_ L_A_review

Sims, B., Corsi, S., Gbehounou, G., Kienzle, J., Taguchi, M., \& Friedrich, T. (2018). Sustainable weed management for conservation agriculture: Options for smallholder farmers. Agriculture, 8(8), 118. https://doi.org/10.3390/agriculture8080118

Sims, B., Friedrich, T., Kassam, A., \& Kienzle, J. (2009). Agroforestry and conservation agriculture: Complementary practices for sustainable development. Annual General Meeting, Royal Overseas League, 9 December 2009., II World Congress of Agroforestry, Nairobi, Kenya, 23-28 August 2009.; TAA South-West Group meeting on Ethiopia - a review of some conservation, 8, 13-18. Retrieved from https://www.cabdirect.org/ cabdirect/abstract/20103040585

Siregar, B. H., \& Nugroho, A. (2020). Potensi ekstrak daun pinus (Pinus merkusii) Sebagai bioherbisida terhadap gulma teki (Cyperus rotundus L.). Jurnal Produksi Tanaman, 8(4), 363-369. Retrieved from http://protan.student journal.ub.ac.id/index.php/protan/article/view $/ 1394$

Siregar, E. N., Nugroho, A., \& Sulistyono, R. (2017). Uji alelopati ekstrak umbi teki pada gulma bayam duri (Amaranthus spinosus L.) dan pertumbuhan tanaman jagung manis (Zea mays L. saccharata). Jurnal Produksi Tanaman, 5(2), 290-298. Retrieved from https://media.neliti.com/media/publications/1 90356-ID-none.pdf

Suryaningsih, Joni, M., \& Darmadi, A. A. K. (2011). Inventarisasi gulma pada tanaman jagung (Zea mays L.) di lahan sawah Kelurahan Padang Galak, Denpasar Timur, Kodya Denpasar, Provinsi Bali. Jurnal Simbiosis, 1(1), 1-8. Retrieved from https:// ojs.unud.ac.id/index.php/simbiosis/article/vie w/5494

Susanti, D., \& Safrina, D. (2018). Identifikasi luas daun spesifik dan indeks luas daun pegagan (Centella asiatica (L.) Urb.) di Karangpandan, Karanganyar, Jawa Tengah. Jurnal Tumbuhan Obat Indonesia, 11(1), 1117. http://dx.doi.org/10.22435/toi.v11i1.8242. 11-17

Syarifah, S., Apriani, I., \& Amallia, R. H. T. (2018). Identifikasi gulma tanaman padi (Oryza sativa L. var. Ciherang) Sumatara Selatan. Jurnal Biosilampari: Jurnal Biologi, 1(1), 40-44. https://doi.org/10.31540/biosilam pari.v1i1.52

Talahatu, D. R., \& Papilaya, P. M. (2015). Pemanfaatan ekstrak daun cengkeh (Syzygium aromaticum L.) sebagai herbisida alami terhadap pertumbuhan gulma rumput teki (Cyperus rotundus L.). Biopendix: Jurnal Biologi, Pendidikan Dan Terapan, 1(2), 160170. https://doi.org/10.30598/biopendixvollis sue2page $160-170$

Widaryanto, E. (1994). Pengaruh herbisida pratumbuh oksifluorfen (Goal 2E) dan kepadatan populasi kacang tanah di lahan kering. Agrivita, 17(2), 65-68. Retrieved from https://scholar.google.com/scholar?hl=en\&as _sdt $=0,5 \&$ cluster $=7266581239208174695$

Widayat, D., \& Purba, C. O. (2015). Produktivitas tanaman dan kehilangan hasil tanaman padi (Oryza sativa L.) kultivar Ciherang pada kombinasi jarak tanam dengan frekuensi 
penyiangan berbeda. Jurnal Kultivasi, 14(1), 17-24. https://doi.org/10.24198/kltv.v14i1.12 098

Xu, Z., \& Chang, L. (2017). Identification and
Control of Common Weeds: Volume 3. Zhejiang University Press, Hangzhou and Springer Nature Singapore Pte Ltd. https://doi.org/10.1007/978-981-10-5403-7 